\title{
Intake of antioxidants in patients with rheumatoid arthritis
}

\author{
Bruna Nolasco Siqueira Silva ${ }^{1 *}$, Ísis lucília Santos Borges de Araújoํㄹ Pedrita Mirella Albuquerque Queiroz², Angela luzia
}

Branco Pinto Duarte ${ }^{3}$, Maria Goretti Pessoa de Araújo Burgos ${ }^{4}$

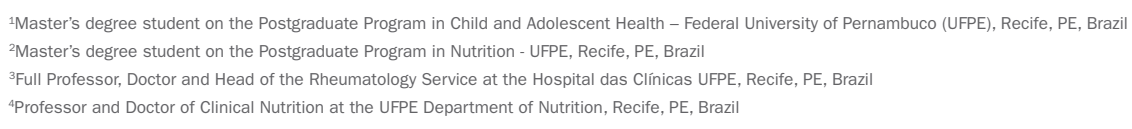

\section{SUMmaRY}

Objective: to investigate dietary intake of antioxidants in patients with rheumatoid arthritis.

Methods: this is a cross-sectional case series study with 53 women accompanied at the Rheumatology Outpatient Clinic, Hospital das Clínicas/UFPE, from January to October 2012. Demographic and anthropometric parameters (weight, height, body mass index, weight change) were collected by means of a form. The assessment of food consumption was conducted using a semi-quantitative food frequency survey, analyzed according to a food composition table. Database construction and statistical analysis were performed using Excel and SPSS version 18.0, using chi-squared test, Anova, and Student's $t$-test, at a confidence level of 5\%.

Results: the sample was composed of 53 women with a mean age of $54.51 \pm 4.24$ years and BMI of $25.97 \pm 5.94 \mathrm{~kg} / \mathrm{m}^{2}$. In the sociodemographic variables, statistically significant differences in origin, occupation, and income were observed. Daily consumption showed significance for vitamins A, C, and zinc. In adults, vitamins $\mathrm{A}$ and $\mathrm{C}$ were in accordance with recommendations, while in the elderly a low intake of vitamin $\mathrm{E}$ and selenium was observed. The relation between vitamin E and origin was significant.

Conclusion: patients demonstrated low consumption of vitamins A, C, and zinc. Therefore, there is a need for increased consumption of foods rich in antioxidants in order to contribute to the prevention of joint injury and loss of rheumatic function, thus, improving quality of life of patients.

Keywords: arthritis, rheumatoid, antioxidants, micronutrients.

\section{INTRODUCTION}

Rheumatoid arthritis (RA) is a systemic inflammatory autoimmune disease that affects the synovial membrane of peripheral joints. Prevalence is estimated at 0.5 to $1 \%$ of the population, predominantly in women, with a greater incidence in the age group of 30-50 years. ${ }^{1}$ In Brazil, a multicenter study verified the prevalence of adult RA as ranging from 0.2 to $1 \%{ }^{2}$

It is characterized by local and systemic inflammation with high plasma concentrations of proinflammatory cytokines, such as interleukin-6, interleukin $1 \beta$, tumor necrosis factor- $\alpha$ and acute phase proteins, characterizing a condition of oxidative stress. The disease could be related to genetic susceptibility, manifesting itself in response to an environmental stimulus. However, the exact cause or causes of the disease are unknown. ${ }^{3}$

The term oxidative stress is defined as a pro-oxidant disorder leading to cellular damage. Various cells can tolerate mild oxidative stress, as they have the ability of antioxidant defense and a repair system, which recognize and remove molecules damaged by oxidation ${ }^{4}$ including antioxidant enzymes, which constitute the first defense for neutralization of endogenous reactive oxygen species (EROS) as well as antioxidant nutrients.

Antioxidant nutrients are substances that at low concentrations delay or minimize the oxidation of oxidizable substrates. ${ }^{5}$ Among non-enzymatic antioxidants responsi- 
ble for lower molecular and cellular oxidative stress, vitamin A, C and E, zinc and selenium deserve special attention. ${ }^{6}$

Progress in clinical research has demonstrated an association between antioxidant nutrients intake and lower formation of free radicals, as well as aspects related to the pathogenesis of the disease, ${ }^{7}$ showing that these antioxidants effectively suppress the release of inflammatory cytokines, reducing $\mathrm{EROS}^{8}$ and presenting a protective effect on the development of RA. ${ }^{9}$

The purpose of this study was to evaluate the dietary intake of antioxidant micronutrients, associating this with sociodemographic variables, nutritional status, age range and weight change after use of antirheumatic drugs.

\section{Methods}

This was a cross-sectional case series study lasting for 10 months (2012), in which 53 women with RA were assessed at the Rheumatology Outpatient Service of Hospital das Clínicas, Federal University of Pernambuco (HC/UFPE), Recife/state of Pernambuco. Patients aged $\geq 20$ years from urban and rural areas of Pernambuco were included.

Patients who did not know their precise feed consumption were excluded, as well as amputees, pregnant women, nursing mothers and those in advanced stages of the disease.

Sociodemographic and anthropometric parameters (age, gender, origin, marital status, occupation, family income, education level) were evaluated, as well as measurements of weight $(\mathrm{kg})$, height $(\mathrm{m})$ and Body Mass Index (BMI) $\left(\mathrm{kg} / \mathrm{m}^{2}\right)$, classified according to the World Health Organization $(2002)^{10}$ for adults, and Lipschitz ${ }^{11}$ for seniors.

Furthermore, patients were classified according to the presence of weight changes. ${ }^{12}$ They first reported their usual weight before the rheumatic disease, in order to observe weight gains, maintenance or loss related to current weight, with or without the use of antirheumatic drugs.

Food consumption was assessed at a daily frequency using a dietary frequency semi-quantitative questionnaire (QFASQ), adapted by Rohenkohl, ${ }^{13}$ structured into five distinct groups of micronutrients: vitamin A, vitamin C, vitamin E, Zinc and Selenium. This was done using Brazilian food sources with reasonable amounts of these micronutrients and frequently consumed by the Brazilian population, and based on the food composition table by Philippi. ${ }^{14}$ An illustrative album with usual cooking measures was used for appropriate portioning and the table of food composition by Philippi ${ }^{14}$ was used to analyze the frequency of food consumption.

The study was approved by the Ethics Committee for research involving human subjects at the Health Sciences Center/UFPE under number 0510.0.172.000-11.

\section{Statistical analysis}

The construction of the database and the statistical analysis were performed using Excel and the Statistical Package for Social Sciences (SPSS) version 18.0 (SPSS Inc., Chicago, IL, USA), respectively.

The continuous variables were tested for normality using the Kolmogorov-Smirnov test, when necessary. Variables with normal distribution were described in the form of means and their respective standard deviations.

While verifying the occurrence of statistical associations, chi-squared, Anova and Student's $t$-test were used to compare means, presenting their respective $\mathrm{p}$-value for determination of statistical significance. The prevalence ratio was used as a measure of effect, considering food intake of the main antioxidants in patients as the dependent variable. A confidence level of $5 \%$ was adopted for rejection of the null hypothesis.

\section{Results}

The study consisted of 53 women with a mean age of 54.51 \pm 4.24 years (70\% adults and $30 \%$ seniors), with a mean BMI of $25.97 \pm 5.94 \mathrm{~kg} / \mathrm{m}^{2}$. There was no association between weight change and the use of antirheumatic drugs.

Table 1 presents sociodemographic and clinical characteristics of the sample. Being from urban areas, employed and with an income of 1-3 minimum wages were significant characteristics in the group. It is noteworthy that no differences were detected in other parameters, although there was a trend toward a greater number of literate and overweight individuals.

In relation to daily consumption of antioxidant micronutrients between age groups (Table 2), we observed a significantly higher intake in of vitamin $\mathrm{A}, \mathrm{C}$ and zinc in seniors. Adequacy of consumption using the DRIs was greater than $100 \%$ for vitamin $A$ and $C$ in adults, with inadequate intake of vitamin $\mathrm{E}$ and selenium in seniors.

Table 3 shows the comparison between sociodemographic factors and inadequate intake of micronutrients (vitamin E, selenium and zinc). 
TABLE 1 Association of sociodemographic, anthropometric and clinical characteristics of the sample $(n=53)$

\begin{tabular}{l|l|l|l|l} 
Variables & N (\%) & Mean & $\begin{array}{l}\text { Standard } \\
\text { deviation }\end{array}$ & p Value \\
\hline
\end{tabular}

\section{Origin}

\begin{tabular}{l|l|l|l|l}
\hline Urban area & $29(54.7 \%)$ & 57.55 & 11.76 & $0.040^{*}$ \\
\hline Rural area & $24(45.3 \%)$ & 50.83 & 11.27 & \\
\hline Marital status & $28(52.8 \%)$ & 56.50 & 12.56 & 0.201 \\
\hline $\begin{array}{l}\text { Single/widowed/ } \\
\text { divorced }\end{array}$ & $25(47.2 \%)$ & 52.28 & 10.98 & \\
\hline $\begin{array}{l}\text { Married/common- } \\
\text { law partner }\end{array}$ & & & & \\
\hline
\end{tabular}

\begin{tabular}{l|l|l|l|l}
\hline Occupation & \multicolumn{5}{l}{$l$} \\
\hline Employed & $41(77.4 \%)$ & 56.68 & 10.94 & $0.013^{*}$ \\
\hline Unemployed & $12(22.6 \%)$ & 47.08 & 12.59 & \\
\hline
\end{tabular}

Income

\begin{tabular}{l|l|l|l|l}
\hline No income & $6(11.3 \%)$ & 48.00 & 13.71 & \\
\hline$<1$ minimum salary & $8(15.1 \%)$ & 46.38 & 12.43 & $0.021^{* *}$ \\
\hline $\begin{array}{l}1-3 \text { minimum } \\
\text { salaries }\end{array}$ & $39(73.6 \%)$ & 57.18 & 10.64 & \\
\hline
\end{tabular}

Education

\begin{tabular}{l|l|l|l|l}
\hline Illiterate & $5(9.4 \%)$ & 55.40 & 4.56 & 0.863 \\
\hline Literate & $48(90.6 \%)$ & 54.42 & 12.46 & \\
\hline Nutritional status & & & & \\
\hline Low weight & $4(7.7 \%)$ & 56.75 & 14.84 & \\
\hline Normal weight & $18(34.6 \%)$ & 52.56 & 13.12 & 0.856 \\
\hline Overweight & $19(36.5 \%)$ & 55.58 & 12.69 & \\
\hline Obese & $11(21.2 \%)$ & 55.27 & 8.81 & \\
\hline
\end{tabular}

Antirheumatic drugs

\begin{tabular}{l|l|l|l|l}
\hline One drug & $27(50.9 \%)$ & 51.93 & 9.57 & 0.108 \\
\hline Two or more drugs & $26(49.1 \%)$ & 57.19 & 13.62 & \\
\hline
\end{tabular}

*T-test; **ANOVA.

\section{Discussion}

A mean of $54.51 \pm 4.24$ years was observed in this study, with a predominance of women, confirming the findings of most authors ${ }^{13,15}$ who assessed the intake of antioxidants.

In relation to BMI, our results are in agreement with Avelar, Melo and Souza ${ }^{16}$ in a study of a group similar to this one, where a BMI of $26.39 \pm 3.80 \mathrm{~kg} / \mathrm{m}^{2}$ was found. On the other hand, Fernandes et al. ${ }^{17}$ found a higher percentage of obesity in their sample, where $68.3 \%$ had some degree of obesity.

The data in the literature is scarce when relating the intake of antioxidants and/or rheumatic diseases with patient origin and per capita income. According to some authors, ${ }^{18,19}$ rheumatic patients are a group with prevalent inactivity (around 30\%), which is also seen in this study. Corbacho and Dapueto, ${ }^{20}$ with an equal number of individuals and pathology as this study, observed similar results in terms of education, although different in relation to antirheumatic drug therapy, with only $24.5 \%$ using combined treatment.

Evidence suggests a high intake of vitamin $\mathrm{C}$ and low of vitamin $\mathrm{E}$ when assessing the dietary intake of women with $\mathrm{RA},{ }^{15}$ a result similar to this group. Edmonds et al. ${ }^{21}$ have shown that vitamin E supplementation (600 $\mathrm{mg} /$ day) improves the clinical symptoms of the disease, through a possible mechanism of reduced formation of prostaglandins, molecules produced during inflammatory processes.

When evaluating selenium intake, Salvador et al. ${ }^{15}$ detected that $90 \%$ of the sample had a higher consumption than the recommendations, a fact confirmed by Hagfors et al. ${ }^{22}$ and not verified by this study, which found inadequacy greater than $40 \%$ of the DRIs. Current data confirms the importance of selenium in RA, since deficiency is associated with increased incidence of the disease. ${ }^{23}$

TABLE 2 Adequacy of dietary intake of antioxidants and comparison between age groups ( $\mathrm{n}=53$ )

\begin{tabular}{l|l|l|l|l|l|l|l} 
Nutrients & Average intake & Reference value (DRIs) & Adults & Adequacy \% & Elderly & Adequacy \% & p Value \\
\hline Vitamin A $(\mu \mathrm{g})$ & 953.81 & 700 & 838.17 & 119.74 & 1221.23 & 174.46 & $0.037^{*}$ \\
\hline Vitamin C (mg) & 147.15 & 75 & 117.72 & 156.96 & 215.19 & 286.92 & $0.036^{*}$ \\
\hline Vitamin E (mg) & 8.51 & 15 & 8.83 & 58.87 & 7.77 & 51.80 & 0.505 \\
\hline Selenium ( $\mu \mathrm{g})$ & 24.48 & 55 & 22.09 & 40.16 & 30.01 & 54.56 & 0.283 \\
\hline Zinc $(\mathrm{mg})$ & 5.77 & 8 & 4.73 & 59.12 & 8.17 & 102.12 & $0.038^{*}$ \\
\hline
\end{tabular}

* Student's t-test; Dietary Reference Intake (DRIs) 2000: vitamins E, C, selenium and 2001: vitamin A, zinc. 
TABLE 3 Relationship between sociodemographic characteristics and food consumption ( $\mathrm{n}=53$ )

\begin{tabular}{|c|c|c|c|c|c|c|c|c|c|}
\hline Variables & & Vitamin E & & & Selenium & & & Zinc & \\
\hline & Mean & $\begin{array}{l}\text { Standard } \\
\text { deviation }\end{array}$ & p Value & Mean & $\begin{array}{l}\text { Standard } \\
\text { deviation }\end{array}$ & p Value & Mean & $\begin{array}{l}\text { Standard } \\
\text { deviation }\end{array}$ & p Value \\
\hline \multicolumn{10}{|l|}{ Origin } \\
\hline Urban & 6.97 & 4.46 & $0.017^{*}$ & 28.31 & 25.84 & $0.213 *$ & 6.24 & 5.17 & $0.507^{*}$ \\
\hline Rural & 10.38 & 5.64 & & 19.86 & 22.23 & & 5.20 & 6.11 & \\
\hline \multicolumn{10}{|l|}{ Marital status } \\
\hline Single/widowed/divorced & 9.33 & 4.79 & $0.234^{*}$ & 29.65 & 26.34 & $0.103^{*}$ & 6.96 & 5.96 & $0.102^{*}$ \\
\hline Married/common-law partner & 7.60 & 5.71 & & 18.69 & 21.09 & & 4.44 & 4.91 & \\
\hline \multicolumn{10}{|l|}{ Occupation } \\
\hline Employed & 8.43 & 5.23 & $0.843^{*}$ & 27.07 & 25.67 & $0.155^{*}$ & 6.51 & 5.55 & $0.076^{*}$ \\
\hline Unemployed & 8.78 & 5.62 & & 15.64 & 17.64 & & 3.26 & 5.16 & \\
\hline \multicolumn{10}{|l|}{ Income } \\
\hline No income & 7.99 & 6.86 & & 19.52 & 18.21 & & 4.47 & 6.61 & \\
\hline$<1$ minimum salary & 8.52 & 4.60 & $0.968 * *$ & 12.08 & 15.79 & $0.223 * *$ & 2.49 & 3.53 & $0.132^{* *}$ \\
\hline 1-3 minimum salaries & 8.59 & 5.27 & & 27.79 & 26.05 & & 6.64 & 5.59 & \\
\hline \multicolumn{10}{|l|}{ Education } \\
\hline Illiterate & 10.76 & 6.13 & $0.320^{*}$ & 18.19 & 26.83 & $0.550 *$ & 4.16 & 5.82 & $0.503^{*}$ \\
\hline Literate & 8.23 & 5.18 & & 25.14 & 24.36 & & 5.94 & 5.59 & \\
\hline
\end{tabular}

*T-test; ** Anova

Regarding the consumption of vitamin A, Bae et al. ${ }^{24}$ observed that daily intake was significantly lower in RA patients than in the control group, which was not demonstrated by this study.

The current literature is sparse in relation to the association between antioxidant intake and nutritional status in rheumatic diseases. In healthy obese individuals, Marreiro et al. ${ }^{25}$ found a reduction in plasma concentrations of zinc, demonstrating that supplementation reduces insulin resistance. These findings demonstrate the influence of this antioxidant on changes in nutritional status, which was observed in our results.

Few studies have compared the intake of micronutrients and sociodemographic factors. A study ${ }^{26}$ conducted in Brazil suggests that vitamin $\mathrm{E}$ intake is inadequate, regardless of gender, age, race, income, social class and nutritional status, corroborating the results of this group. On the other side, $13.4 \%$ inadequate intake of selenium was also shown, contrary to the results in this study (55\%). In relation to zinc, $52.1 \%$ inadequacy was found the entire sample, similar to this study on adults $(40 \%)$. However, in this Brazilian case series, micronutrient intakes were not associated with sociodemographic factors.

In relation to the use of the RA medication, anti-inflammatory and immunomodulatory drugs are important in the treatment of patients with RA, although this may occasionally be a cause of troubling metabolic effects (obe- sity, glucose intolerance, weight and appetite changes). ${ }^{27}$ However, the patient may occasionally present persistent anorexia, decreased absorption and/or abnormal utilization of nutrients, promoting hypercatabolism, malnutrition and changes in the bodily composition, ${ }^{28}$ confirming the findings of this study, which detected a greater tendency to weight loss in the group as a whole and within the different age ranges.

\section{Conclusion}

This research has shown that patients with RA had a low consumption of antioxidant micronutrients: vitamins A, $\mathrm{C}$ and zinc. Therefore, we can emphasize the importance of dietary guidance based on major sources of antioxidant micronutrients, especially fruits, raw vegetables, fish and oilseeds in order to contribute to the prevention of joint damage and loss of rheumatic function.

\section{Resumo}

Consumo de antioxidantes em portadores de artrite reumatoide.

Objetivo: investigar o consumo alimentar de antioxidantes em pacientes portadores de artrite reumatoide.

Métodos: estudo transversal do tipo série de casos com 53 mulheres acompanhadas no Ambulatório de Reumatolo- 
gia do Hospital das Clínicas da Universidade Federal de Pernambuco (HC-UFPE), de janeiro a outubro de 2012. Por meio de formulário, foram coletados parâmetros sociodemográficos e antropométricos (peso, estatura, índice de massa corpórea [IMC], alteração ponderal). A avaliação do consumo alimentar foi realizada por questionário de frequência alimentar semiquantitativo, analisado por tabela de composição de alimentos. A construção do banco de dados e a análise estatística foram realizadas por Excel e SPSS versão 18.0, com aplicação de testes Qui-quadrado, Anova e t-Student, com nível de confiança de 5\%.

Resultados: amostra composta por 53 mulheres, idade de $54,51 \pm 4,24$ anos e IMC de $25,97 \pm 5,94 \mathrm{~kg} / \mathrm{m}^{2}$. Nas variáveis sociodemográficas, observou-se diferença estatística em procedência, ocupação e renda. O consumo diário apresentou significância para as vitaminas $\mathrm{A}, \mathrm{C}$ e zinco. Nos adultos, as vitaminas A e C estavam de acordo com as recomendações; nos idosos, houve baixo consumo de vitamina E e selênio. Foi significativo ao relacionar a vitamina $\mathrm{E}$ com a variável procedência.

Conclusão: demonstrou-se que os pacientes apresentaram baixo consumo de vitaminas A, C e zinco. Portanto, ressalta-se a importância de maior consumo de alimentos fontes em antioxidantes, a fim de contribuir para a prevenção da lesão articular e a perda da função reumática, melhorando a qualidade de vida do paciente.

Palavras-chave: artrite reumatoide; antioxidantes; consumo alimentar.

\section{RefEREnCES}

1. Alamanos Y, Voulgari PV, Drosos AA. Incidence and prevalence of rheumatoid arthritis, based on the 1987 American College of Rheumatology criteria: a systematic review. Semin Arthritis Rheum. 2006;36(3):182-8.

2. Marques Neto JF, Goncalves ET, Barros EFO, Cunha MFL, Radominsk S, Oliveira SM, et al. Estudo multicêntrico da prevalência da artrite reumatoide do adulto em amostras da população brasileira. Rev Bras Reumatol. 1993;33(5):169-73.

3. Rennie KL, Hughes J, Lang R, Jebb SA. Nutritional management of rheumatoid arthritis: a review of the evidence The British Dietetic Association. J Hum Nutr Diet. 2003;16(2):97-109.

4. Zadák Z, Hyspler R, Tichá A, Hronek M, Fikrová P, Rathouská J, et al. Antioxidants and vitamins in clinical conditions. Physiol Res. 2009;58(1):13-7.

5. Halliwell B, Aeschbach R, Löliger J, Aruoma OI. The characterization of antioxidants. Food Chem Toxicol. 1995;33(7):601-17.

6. Berger MM. Can oxidative damage be treated nutritionally? Clin Nutr. $2005 ; 24(2): 172-83$
7. Riccioni G, Bucciarelli T, Mancini B, Corradi F, Di Ilio C, Mattei PA, et al. Antioxidant vitamin supplementation in cardiovascular diseases. Ann Clin Lab Sci. 2007;37(1):89-95.

8. Surh YJ, Kundu JK, Na HK, Lee JS. Redox-sensitive transcription factors as prime targets for chemoprevention with anti-inflammatory and antioxidative phytochemicals. J Nutr. 2005; 135(12):2993-3001.

9. Pattison DJ, Harrison RA, Symmons DPM. The role of diet in susceptibility to rheumatoid arthritis: a systematic review. J Rheumatol 2004;31(7):1310-9

10. World Health Organization: the world report 2002: reducing risks, promoting healthy life. Geneve: World Health Organization; 2002.

11. Lipschitz DA. Screening for nutritional status in the elderly. Prim Care. 1994;21(1):55-67

12. Blackburn GL, Bristian BR. Nutritional and metabolic assessment of the hospitalized patient. JPEN J Parenter Enteral Nutr. 1977;1(1):11-22.

13. Rohenkohl CC, Carniel AP, Colpo E. Consumo de antioxidantes durante tratamento quimioterápico. ABCD Arq Bras Cir Dig. 2011;24(2):107-12.

14. Philippi ST. Tabela de composição de alimentos: suporte para decisão nutricional. 2a ed. São Paulo: Editora Coronário; 2002.

15. Salvador MB, Sarkis KS, Silva RG, Zerbini CAF, Martini LA. Avaliação da ingestão de ácidos graxos, antioxidantes e da composição corporal em mulheres com artrite reumatoide. Rev Soc Bras Alim Nutr. 2008;33(3):17-30.

16. Avelar AB, Melo AKG, Souza BDB. Avaliação prospectiva do perfil lipídico na artrite reumatóide. Rev Bras Reumatol. 2008;48(4):213-7.

17. Fernandes M, Paes C, Nogueira C, Souza G, Aquino L, Borges F et al. Perfil de consumo de nutrientes antioxidantes em pacientes com síndrome metabólica. Rev Ciênc Méd. 2007;16(4-6):209-19.

18. Abreu MM, Kowalski SC, Ciconelli RM, Ferraz MB. Avaliação do perfil sociodemográfico, clínico-laboratorial e terapêutico dos pacientes com artrite reumatóide que participaram de projetos de pesquisa na Escola Paulista de Medicina, nos últimos 25 anos. Rev Bras Reumatol. 2006;46(2):103-9.

19. Louzana-Junior P, Souza BDB, Toledo RA, Ciconelli RM. Análise descritiva das características demográficas e clínicas de pacientes com artrite reumatóide no Estado de São Paulo, Brasil. Rev Bras Reumatol 2007;47(2):84-90.

20. Corbacho MI, Dapueto JJ. Avaliação da capacidade funcional e da qualidade de vida de pacientes com artrite reumatoide. Rev Bras Reumatol. 2010;50(1):31-43.

21. Edmonds SE, Winyard PG, Guo R, Kidd B, Merry P, Lnagrish-Smith A, et al. Putative analgesic activity of repeated oral doses of vitamina $\mathrm{E}$ in the treatment of rheumatoid arthritis. Results of a prospective placebo controlled double blind trial. Ann Rheum Dis. 1997;56(11):649-55.

22. Hagfors L, Leanderson P, Sköldstam L, Andersson J, Johansson G. Antioxidant intake, plasma antioxidants and oxidative stress in a randomized, controlled, parallel, Mediterranean dietary intervention study on patients with rheumatoid arthritis. Nutr J. 2003;2(1):1-11.

23. Cerhan JR, Saag KG, Merlino LA, Mikuls TR, Criswell LA. Antioxidant micronutrients and risk of rheumatoid arthritis in a cohort of older women. Am J Epidemiol. 2003;157(4):345-54.

24. Bae S, Jung W, Lee E, Yu R, Sung M. Effects of antioxidant supplements intervention on the level of plasma inflammatory molecules and disease severity of rheumatoid arthritis patients. J Am Coll Nutr. 2009;28(1):56-62

25. Marreiro DN, Fisberg M, Cozzolino SM. Zinc nutritional status and its relationships with hyperinsulinemia in obese children and adolescents. Biol Trace Elem Res. 2004;100(2):137-49.

26. Pinheiro MM, Ciconelli RM, Chaves GV, Aquino L, Juzwiak CR, Genaro PS, et al. Antioxidant intake among Brazilian adults - The Brazilian Osteoporosis Study (BRAZOS): a cross-sectional study. Nutr J. 2011;10(39):1-8.

27. Castro TDM, Obana FK, Martins MFM, Andrade CAF. Efeitos adversos metabólicos dos glicocorticóides notratamento da artrite idiopática juvenil: uma revisão sistemática. Rev Saúde. 2010;1(2)31-42.

28. Chaud DMA, Hilário MOE, Yanaguibashi G, Amancio OMS. Avaliações dietética e antropométrica em pacientes com artrite reumatoide juvenil. Rev Assoc Med Bras. 2003;49(2):181-4. 